\title{
An Optimised TRIzol-based Protocol for the Improvement of RNA Extraction Yield of Tomato Stem
}

\author{
Anis Afifah ${ }^{1}$, Prachumporn Nounurai', Rejeki Siti Ferniah ${ }^{3}$, Hermin Pancasakti \\ Kusumaningrum $^{3}$, Dyah Wulandari ${ }^{4,5}$ and Anto Budiharjo ${ }^{3,4 *}$ \\ ${ }^{1}$ Department of Biology, Faculty of Science and Mathematics, Diponegoro University, Jl. Prof Soedharto \\ SH-Semarang 50275, Indonesia \\ ${ }^{2}$ Genome Technology Research Unit, National Centre for Genetic Engineering and Biotechnology (BIOTEC), \\ National Science and Technology Development Agency, 113 Thailand Science Park, Phahonyothin Road, \\ Khlong Luang, Pathumthani 12120, Thailand \\ ${ }^{3}$ Biotechnology Study Program, Diponegoro University, Jl. Prof Soedharto SH - Semarang 50275, Indonesia \\ ${ }^{4}$ Molecular and Applied Microbiology Laboratory, Central Laboratory of Research and Service - Diponegoro \\ University, Jl. Prof. Sudharto SH, Semarang 50275, Indonesia \\ ${ }^{5}$ School of Biotechnology, Institute of Agricultural Technology, Suranaree University of Technology, Nakhon \\ Ratchasima 30000, Thailand
}

\begin{abstract}
One of the most common methods for purifying RNA is using TRIzol reagent because of its simplicity and economic feasibility. However, the drawback of this method is frequently the low quality of extracted RNA due to contaminants from the residue of phenol and guanidinium thiocyanate from the reagents. This study aimed to evaluate the improvement in the quality and concentration of RNA after the optimisation treatment. One-month-old tomato (Solanum lycopersicum) stem was used in this research. TRIzol or acid guanidinium thiocyanate-phenol-chloroform-based method was given optimisation treatments of the initial sample amount, twice chloroform extraction, overnight precipitation

ARTICLE INFO

Article history:

Received: 2 June 2021

Accepted: 26 July 2021

Published: 20 August 2021

DOI: https://doi.org/10.47836/pjtas.44.3.10

E-mail addresses:

anisaf06@gmail.com (Anis Afifah)

Prachumporn.Nou@biotec.or.th (Prachumporn Nounurai)

ferniahmikro@gmail.com (Rejeki Siti Ferniah)

herminsakti@gmail.com (Hermin Pancasakti Kusumaningrum)

wulandaridyah1207@gmail.com (Dyah Wulandari)

anto.budiharjo@live.undip.ac.id (Anto Budiharjo)

*Corresponding author

at low temperature, and three times final washing with ethanol. The results showed no significant improvement $(p>0.05)$ in the purity ratio A260/A280. At the same time, there was a significant improvement ( $p<$ 0.05 ) in RNA yield and purity ratio A260/ A230. The quality of RNA was verified using agarose-formaldehyde electrophoresis gel. Eight of nine samples (89\%) from the optimised group had better RNA integrity characterised by sharp bands for $28 \mathrm{~S}$ and $18 \mathrm{~S}$
\end{abstract}


rRNA. Furthermore, a representative sample from the optimised group was successfully synthesised into complementary DNA by reverse transcriptase-polymerase chain reaction (RT-PCR) with primers of the ubiquitin (UBI3) gene. To sum up, optimised TRIzol-based protocol provides meaningful insight to produce RNA with better quality and suitability for downstream applications.

Keywords: RNA extraction, RT-PCR, Solanum lycopersicum, TRIzol

\section{INTRODUCTION}

Tomato (Solanum lycopersicum) is an important food crop that provides nearly $11 \%$ of daily vegetable calories consumed per capita in 2003 (Liedl et al., 2013) and has consistently increased in the last decades. United States Department of Agriculture reported tomato per capita availability reached an average of 20.7 pounds by 2010 2017 (Baskins et al., 2019). However, not a part of the primary source of calories, scientific interest in tomatoes peaked after its development as a genome model of the Solanaceae family, containing many other important plant species such as potatoes and chillies. Various molecular investigations such as quantitative trait mapping, mutant screening, and gene expression analysis in tomatoes began to be carried out in the early 20th century (Giovannoni, 2004). One of the essential investigations is the molecular analysis of plant response to the environment, such as drought stress (Zhou et al., 2019), pathogen attack, bacterial wilt
(Hyakumachi et al., 2012), and Fusarium wilt (Ferniah et al., 2015; Jaiswal et al., 2020). Analysis of plant responses in various stress conditions is studied through gene expression in plant organs, including stem organs.

The difficulties of research in gene expression are due to the low quality and quantity of RNA products from stem organs. On the other hand, plant stem is a resource of molecular analysis underlying plant defence as some of the most destructive plant diseases target the vascular system, specifically the xylem (Yadeta \& Thomma, 2013). Purification of RNA from stem organs has its challenges because of the fibrous nature of the tissue that also contains many secondary metabolites such as polyphenols, polysaccharides, and various other compounds that can affect the final quality of RNA (Farrell Jr., 2017; Rajakani et al., 2013). For example, Wang et al. (2009) stated that RNA extraction of the tomato plant from various organs using a guanidinium thiocyanate-phenolchloroform-based method showed lower RNA yield from stem than other organs such as leaves and roots. The low yield of RNA was presumably due to stems of tomatoes containing high content of polysaccharides and lignin. In addition, the stem of the tomato plant has an average fibre length of $980 \mu \mathrm{m}$, which is equivalent to other hardwood plants that range between 500 and $3000 \mu \mathrm{m}$ (Fengel \& Wegener, 1984; Uner et al., 2016).

Several studies using RNA of tomato stem that has been successfully carried out 
for molecular analysis applications require spin column-based extraction kits, which are relatively expensive (Ishihara et al., 2012; Milling et al., 2011). However, the quality of the RNA itself is not reported. Another standard method is using monophasic reagent based on guanidinium thiocyanatephenol-chloroform, which has now been packaged in commercial forms such as TRIzol (Invitrogen, United States of America), QIAzol (Qiagen, Germany), or GENEzol (Geneaid, Taiwan). The extraction of RNA with the TRIzol reagent has attracted much attention from researchers because of its universal properties and its relatively simple use. However, the standard protocol of this method is not always applicable to all types of cells, especially plant samples that have high fibre and polysaccharide content. Our tomato stem sample has a problem regarding the purity of A260/A280 and A260/A230 below 1.8. RNA extractions that were carried out on several samples such as soybean leaves, potato tubers, wheat seeds, and various medicinal plants with high secondary metabolites using the TRIzol method also did not provide maximum results (Behnam et al., 2019; Bilgin et al., 2009; Ghawana et al., 2011; Vennapusa et al., 2020). The low A260/A280 ratio is due to protein contamination.

In contrast, the low A260/A230 is caused by polysaccharides and residual phenol or guanidinium thiocyanate contamination from the reagent itself (Gallagher, 2017). Modification efforts to optimise the RNA recovery by adding polyvinylpyrrolidone (PVP) reagents (Deepa et al., 2014) and lithium chloride ( $\mathrm{LiCl}$ ) (Wang et al., 2009; Vennapusa et al., 2020) were carried out, but these approaches would add the production costs. Another alternative towards optimising RNA extraction that is often performed by researchers who encounter problems with RNA concentration and purity is adding or changing several mechanical steps. Repetition at the extraction stage using chloroform and washing RNA with ethanol increase RNA recovery both in quantity and quality (Roy et al., 2020; Toni et al., 2018; Vasanthaiah et al., 2008). Therefore, this study aimed was to improve the quantity and quality of RNA using the TRIzol optimisation method for obtaining high-quality RNA from tomato stem, thus providing valuable information for downstream assays.

\section{METHODS}

\section{Sample Preparation}

Commercial Thai tomato (Solanum lycopersicum) seeds are grown on soil mixture (humus, perlite, and vermiculite) in a greenhouse with a temperature of $24^{\circ} \mathrm{C}$, regular sunlight (12 hours per day), and watered daily in the morning or evening depending on soil surface humidity. Tomato stems were collected after one month, cleaned with $70 \%$ alcohol beforehand and flash-frozen in liquid nitrogen before being stored in a $-80^{\circ} \mathrm{C}$ freezer (Sanyo, Japan) to prevent cross-contamination and RNA degradation. The frozen stem samples were ground thoroughly with a mortar and pestle, previously heated at $180^{\circ} \mathrm{C}$ to remove enzymes that cause RNA degradation. The 
grinding process is carried out by repeatedly mixing liquid nitrogen to prevent the sample from thawing.

\section{RNA Extraction and Quality Assessment Using Spectrophotometry}

RNA was extracted from the homogenised sample and was carried out following the TRIzol original method (Invitrogen, United States of America) based on the manufacturer's protocol and an optimised method with changes in the initial sample, i.e., $100 \mathrm{mg}$ increased to $250 \mathrm{mg}$ to $300 \mathrm{mg}$, twice chloroform extraction, and three times ethanol washing which are briefly described in Figure 1.

\section{RNA Extraction}

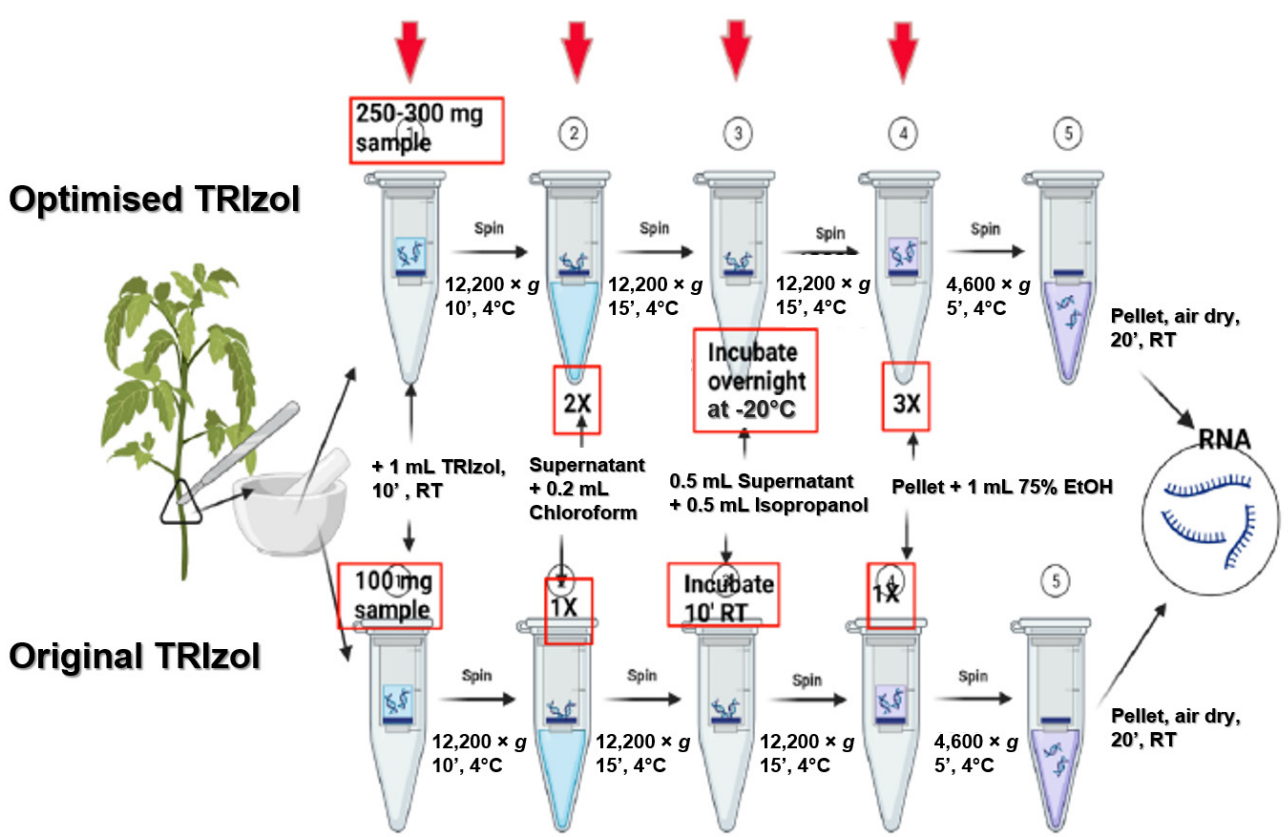

Figure 1. Workflow of RNA extraction using TRIzol reagent: Original protocol (lower part) and optimized protocol (upper part), the key step modification indicated in red arrow and the red square for each modification. Modifications including the initial amount of sample, twice chloroform extraction, overnight incubation in cold temperature, and three times ethanol wash

\section{Optimised Method}

An optimised used a 250 to $300 \mathrm{mg}$ sample per $1 \mathrm{~mL}$ of the TRIzol reagent. The sample and reagent were put into a microtube, homogenised until dissolved and allowed to stand at room temperature for 10 minutes. 
Next, the mixture was centrifuged at $4{ }^{\circ} \mathrm{C}$ temperature and $12,200 \times g$ for 10 minutes. The solution was divided into the aqueous phase (the supernatant) and organic phase. The supernatant was then transferred to a new microtube, $200 \mu \mathrm{L}$ of chloroform was added, homogenised by inverting the microtube for 15 seconds, and allowed to stand for 3 minutes before being centrifuged at $4^{\circ} \mathrm{C}$ and $12,200 \times g$ for another 15 minutes for phase separation. The supernatant was transferred into a new microtube for the second time and then re-extracted with 200 $\mu \mathrm{L}$ of chloroform to separate nucleic acids with proteins and organic compounds from the extraction reagents.

After two steps of chloroform extraction, the aqueous phase was transferred to a new microtube and mixed with cold isopropanol (1:1) for precipitation. The mixture was allowed to stand overnight at $-20^{\circ} \mathrm{C}$, then centrifuged at $4^{\circ} \mathrm{C}$ and $12,200 \times g$ for 10 to 15 minutes to precipitate the pellets containing RNA. Next, the supernatant was discarded. Next, the RNA pellets were washed with $1 \mathrm{~mL} \mathrm{75 \%}$ ethanol [dissolved with diethylpyrocarbonate (DEPC) water], allowed to stand at room temperature, then centrifuged at $4,600 \times g$ for 5 minutes. Agent, the supernatant was discarded. The washing step was repeated up to 3 times to maximise the washing of RNA from salt residues and organic compound residues.

RNA pellets were dried for 20 to 30 minutes at room temperature, dissolved in $20 \mu \mathrm{L}$ of DEPC water, and then incubated at $55^{\circ} \mathrm{C}$ for 10 minutes using a heat block (Eppendorf, Germany) to dissolve. Concentration and purity were analysed using the NanoDrop One Microvolume UV-Vis Spectrophotometer (Thermo Fisher Scientific, United States of America).

\section{Formaldehyde Agarose Electrophoresis Gel}

An electrophoresis gel run was performed to validate the presence of the extracted RNA. A 1.2\% agarose gel was prepared by mixing $1.2 \mathrm{~g}$ of agarose, $10 \mathrm{~mL}$ of $10 \mathrm{x}$ MOPS (3-(N-morpholino)propanesulfonic acid) buffer (Sigma-Aldrich, United States of America), and $90 \mathrm{~mL}$ of DEPC water in Erlenmeyer flask (Pyrex ${ }^{\circledR}$, United States of America). The MOPS buffer composition was adjusted according to Rio et al. (2015). The mixture was heated in the microwave for 1 to 2 minutes until dissolved, then cooled for 5 minutes before adding $1.8 \mathrm{~mL}$ of formaldehyde as a denaturing agent and 1 $\mathrm{mL}$ of ethidium bromide as a staining agent. The mixture was poured into the casting tray and let solidified before being immersed in $1 \mathrm{x}$ MOPS buffer. RNA from each sample was adjusted to $500 \mathrm{ng}$ with DEPC water up to $4 \mu \mathrm{L}$ and then mixed with $4 \mu \mathrm{L} 2 \times$ RNA loading dye. The mixture was heated with a heat block at $70^{\circ} \mathrm{C}$ for 10 minutes and then chilled on ice before being loaded into a gel inside the electrophoresis machine (Analytik Jena, Germany). Electrophoresis was run on $55 \mathrm{~V}$ for 1 hour. The gel was visualised under a UV translluminator (Bio-Rad Laboratories, United States of America). 


\section{Reverse Transcriptase-Polymerase Chain Reaction (RT-PCR)}

Reverse transcriptase PCR was performed to validate the presence of mRNA for gene expression analysis. After sample quality was measured in spectrophotometry and electrophoresis analysis, elimination of genomic DNA from RNA sample and first-strand cDNA synthesis was carried out according to manufacturer's protocol (Thermo Fisher Scientific, United States of America). cDNA samples can be stored at $-20^{\circ} \mathrm{C}$ for long-term storage or used directly for the polymerase chain reaction (PCR) technique. The primers used in this study are the ubiquitin (UBI3) gene with the sequence 5' - AGA AGA AGA CCT ACA CCA AGC C-3' (forward) and 5'-TCC CAA GGG TTG TCA CAT ACA -3' (reverse). UBI3 is a housekeeping gene produced by all cells in normal and stressful conditions (Løvdal \& Lillo, 2009). The reverse transcriptasepolymerase chain reaction (RT-PCR) reaction was carried out with the following reaction mixture: $1 \mu \mathrm{L}$ of cDNA template, $6 \mu \mathrm{L}$ of nanopure water, $1 \mu \mathrm{L}$ of enzyme KAPA SYBR ${ }^{\circledR}$ Fast Master Mix (SigmaAldrich, United States of America), and $2 \mu \mathrm{L}$ of the UBI3 gene primer pair. The reaction was carried out in 30 cycles consisting of 3 minutes of pre-denaturation $\left(95^{\circ} \mathrm{C}\right), 30$ seconds of denaturation $\left(94^{\circ} \mathrm{C}\right), 1$ minute of annealing $\left(60^{\circ} \mathrm{C}\right)$, and 1 minute of extension $\left(72^{\circ} \mathrm{C}\right)$. The RT-PCR products were run in $1.5 \%$ agarose gel electrophoresis. The gel was prepared by mixing $0.75 \mathrm{~g}$ of agarose powder with $50 \mathrm{~mL}$ of $1 \mathrm{x}$ TBE (Tris-borateEDTA) buffer (Sigma-Aldrich, United States of America) and then dissolved in the microwave for 1 minute before pouring it into the casting tray. Two (2) $\mu \mathrm{L}$ of DNA ladder (Thermo Fisher Scientific, United States of America) and cDNA samples were inserted into each well. Electrophoresis was run on $100 \mathrm{~V}$ for 40 minutes. The gel was then visualized using GelDoc UV transluminator (Bio-Rad Laboratories, United States of America).

\section{RESULTS AND DISCUSSION}

A pure RNA value of greater than 1.8 is universally accepted for A260/A280 and A260/A230 absorbance. Previously we tried to obtain RNA from tomato stems using the TRIzol method according to manufacturer protocol. However, the concentration and purity results were low. Therefore, we tried to optimise the method by changing mechanical steps as has been done in previous research with various samples (Behnam et al. 2019; Toni et al., 2018; Roy et al., 2020; Vasanthaiah et al., 2008). The data comparison of both yields is shown in Table 1.

Table 1

Concentration and purity of total RNA obtained from the stem of Solanum lycopersicum with standard and optimized TRIzol protocols

\begin{tabular}{lccc}
\hline Protocol & RNA $(\mu \mathrm{g} / \mu \mathrm{L})$ & A260/A280 & A260/A230 \\
\hline Original/Standard & $0.35 \pm 0.26$ & $1.78 \pm 0.18$ & $0.9 \pm 0.56$ \\
Optimized & $0.76 \pm 0.5$ & $1.88 \pm 0.09$ & $2.07 \pm 0.37$ \\
\hline
\end{tabular}


The use of $100 \mathrm{mg}$ initial sample only produced an average of $0.35 \mu \mathrm{g} / \mu \mathrm{L}$ and low RNA quality by the electrophoresis analysis (Figure 3A). The addition of an initial sample of up to $300 \mathrm{mg}$ was then used accordingly. It resulted in a higher concentration of 0.76 $\mu \mathrm{g} / \mu \mathrm{L}$ (Figure $2 \mathrm{~A}$ ) and good RNA quality (Figure 3B). The sample to solvent ratio was previously made by Roy et al. (2020) on the adipose tissue sample. There is a correlation between the RNA recovery and the initial mass of a sample. RNA yield increased linearly with the addition in sample weight, meaning the increase in mass sample weight up to $300 \mathrm{mg}$ per $1 \mathrm{~mL}$ TRIzol (3:10) affected the increase in RNA recovery. In addition, changes in precipitation conditions are also considered to affect the yield. Farrell Jr. (2017) recommended overnight precipitation for mature cell samples containing high secondary metabolites to ensure the recovery of RNA, which also has been done by Vasanthaiah et al. (2008) in grape tissue rich in polyphenols and polysaccharides. Li et al. (2020) also conducted comparisons of various duration and temperatures of nucleic acid precipitation. The results showed that the highest recovery rate occurred in microRNA (miRNA) samples (61\%) and PCR products (33\%) after overnight precipitation at $-20^{\circ} \mathrm{C}$.

The A260/A230 purity ratio from 9 samples extracted with original protocol which has value of 0.9 increased to 2.07 after optimization ( $p=0.001<0.05$, Figure $2 \mathrm{C})$. Most of the samples extracted with the original protocol had a ratio of A260/A230 below 1.8, which indicated the presence of contamination such as polysaccharides, salts, and residual extraction reagents. This problem also occurred in previous studies using soybean leaf samples by Bilgin et al. (2009) and wheat seed samples by Vennapusa et al. (2020), which had A260/ A230 ratios of 0.94 and 0.51 , respectively. The results of the optimisation protocol in this study showed a significant improvement compared to the results of the standard protocol, which almost entirely did not meet the general standard A260/A230 ratio above 1.8. Therefore optimisation steps are highly recommended for RNA extraction from plant samples. Farrell Jr. (2017) stated that the repetition of chloroform extraction in the extraction stage for the second time could separate the remaining phenol from the aqueous phase in an equilibrium state after the first phase separation. A mixture of phenol and chloroform has also been shown to increase the yield of poly $(\mathrm{A})^{+}$ chain ends in mRNA, which has increased mRNA stability (Farrell Jr., 2017). For optimisation, the repetition has also been carried out in the final washing step, which removed extraction reagent residues (phenol and guanidinium thiocyanate) and most of the salts used to catalyse the deposition of nucleic acid molecules during precipitation.

The A260/A280 purity ratio of the optimised group gave a value of 1.88 , slightly increased from the standard group (1.78) but statistically non-significant ( $p$ $=0.309>0.05$, Figure 2B). It shows that the optimisation performed on optimised protocol does not have much effect in increasing the ratio. Previous research that 
used the TRIzol method in plant samples by Bilgin et al. (2009) and Vennapusa et al. (2020) also produced an A260/A280 ratio in the range of 1.88 to 1.98 , meaning that the TRIzol original protocol alone could produce an adequate A260/A280 ratio from plant samples rich of secondary metabolites. However, the optimisation protocol is suggested if the sample does not meet the value above 1.8 .
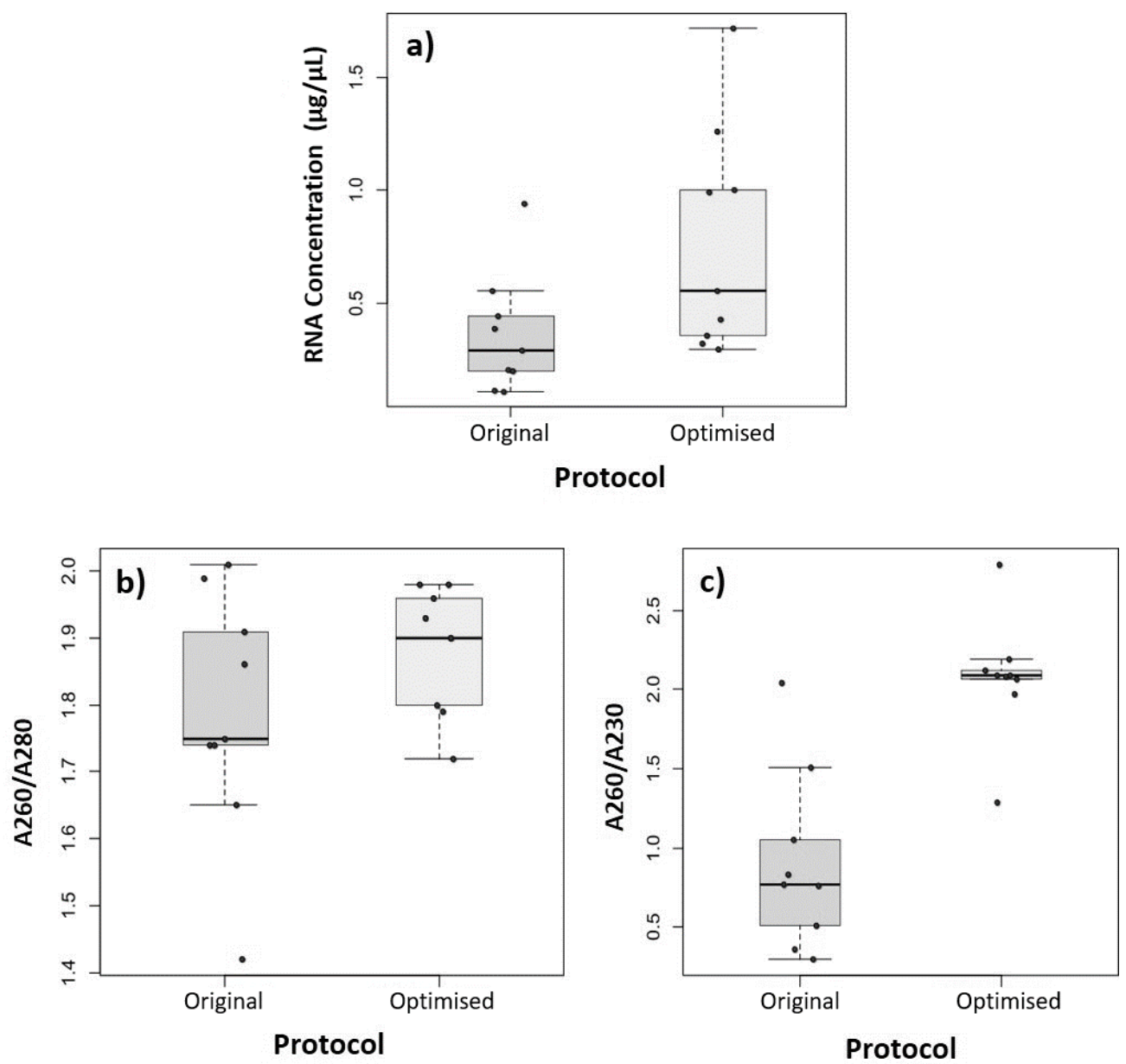

Figure 2. Box-and-Whisker Plot of RNA yield comparison from original and optimized protocols: (A) RNA concentration; (B) A260/A280 ratio; and (C) A260/A230 ratio (n=9)

RNA integrity was then validated Russell, 2001) with three bands of different using the formaldehyde gel electrophoresis technique with standard TAE (Tris-acetatesizes as the indicator. Smear band and lack EDTA)-based agarose gels (Sambrook \& of $28 \mathrm{~S}$ and 18S RNA intensity indicate low RNA quality from the samples extracted 
with a standard protocol (Figure 3A). Similar results of electrophoresis band in plant RNA extracted by TRIzol, which has a purity of A260/A230 below 2.0, also occurred in Dendrobium huosanense sample (0.15-0.68) (Liu et al., 2018) and Triticum aestivum sample (0.51) (Vennapusa et al., 2020). In contrast, bright bands of RNA indicate the presence of good quality RNA, which could be seen in 8 of 9 samples from the optimised group (Figure 3B).
One of the samples with good quality both from spectrophotometry and electrophoresis (lane 2, Figure 3B) was used for further investigation in RT-PCR using the ubiquitin gene (UBI3) of the housekeeping genes that are always expressed in various conditions, including pathophysiological stress. The result showed that RNA samples were successfully converted into cDNA and used to analyse the expression of the gene, marked by a distinct 345 bp DNA band (Figure 4).

\section{Original}
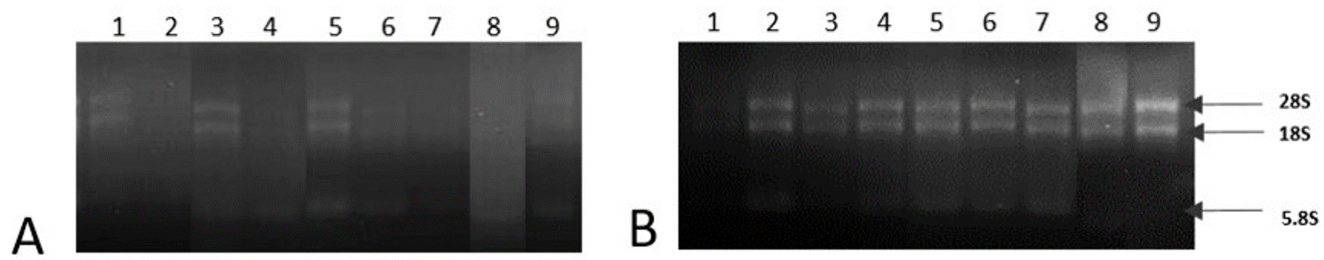

Figure 3. A 1.2\% agarose electrophoresis gel of total RNA (9 samples) extracted using: (A) original TRIzol protocol and (B) optimized TRIzol protocol

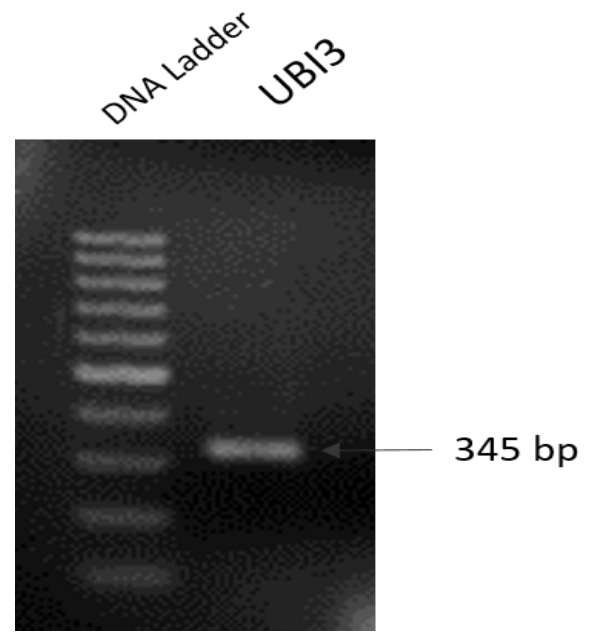

Figure 4. RT-PCR profile from Solanum lycopersicum housekeeping gene ubiquitin (UBI3) primer using RNA as template from optimized protocol 


\section{CONCLUSION}

This optimised TRIzol-based protocol was proven to yield a higher quantity and quality of extracted RNA from tomato stems. The optimisation steps include adding the initial sample amount up to three times, twice chloroform extraction, overnight incubation in low temperature $\left(-20^{\circ} \mathrm{C}\right)$, and three times ethanol washing. The improvement in RNA quality was seen from the A260/A230 ratio, which significantly increased, indicating the treatments successfully purified RNA from contamination of organic residues such as salt and phenol. Improvement of the A260/ A230 ratio could improve RNA, proven by the entire electrophoresis band of 8 from 9 RNA samples (89\%) in the optimised group. RNA with good concentration and purity from the optimised group was used for reverse transcriptase-polymerase chain reaction (RT-PCR) and resulted in the amplicon band of ubiquitin gene.

\section{ACKNOWLEDGMENTS}

AB would like to thank the Ministry of Education and Culture, the Republic of Indonesia for providing PTUPT Grant no. 101-123/UN7.6.1/PP/2018.

\section{CONFLICT OF INTEREST}

No potential conflict of interest was reported by the author(s).

\section{REFERENCES}

Baskins, S., Bond, J., \& Minor, T. (2019). Unpacking the growth in per capita availability of fresh market tomatoes. https://www.ers.usda. gov/webdocs/outlooks/92442/vgs-19c-01. pdf? $\mathrm{v}=5296.1$
Behnam, B., Bohorquez-Chaux, A., CastanedaMendez, O. F., Tsuji, H., Ishitani, M., \& Becerra Lopez-Lavalle, L. A. (2019). An optimized isolation protocol yields high-quality RNA from cassava tissues (Manihot esculenta Crantz). FEBS Open Bio, 9(4), 814-825. https:// doi.org/10.1002/2211-5463.12561

Bilgin, D. D., DeLucia, E. H., \& Clough, S. J. (2009). A robust plant RNA isolation method suitable for Affymetrix GeneChip analysis and quantitative real-time RT-PCR. Nature Protocols, 4(3), 333-340. https://doi.org/10.1038/nprot.2008.249

Deepa, K., Sheeja, T. E., Santhi, R., Sasikumar, B., Cyriac, A., Deepesh, P. V., \& Prasath, D. (2014). A simple and efficient protocol for isolation of high quality functional RNA from different tissues of turmeric (Curcuma longa L.). Physiology and Molecular Biology of Plants, 20(2), 263-271. https://doi.org/10.1007/ s12298-013-0218-y

Farrell Jr., R. E. (2017). RNA methodologies: Laboratory guide for isolation and characterization (5th ed.). Academic Press.

Fengel, D., \& Wegener, G. (1984). Wood-Chemistry, ultrastructure, reactions. Walter de Gruyter.

Ferniah, S. R., Kasiamdari, R. S., Priyatmojo, A., \& Daryono, B. S. (2015). Expression of class II chitinase Gene in chilli (Capsicum annuum L.) as response to Fusarium oxysporum pathogen attack. Asian Journal of Plant Pathology, 9(3), 142-147. https://doi.org/10.3923/ ajppaj.2015.142.147

Gallagher, S. R. (2017). Quantitation of DNA and RNA with absorption and fluorescence spectroscopy. Current Protocols in Immunology, 116(1), A.3L.1-A.3L.14. https:// doi.org/10.1002/cpim.20

Ghawana, S., Paul, A., Kumar, H., Kumar, A., Singh, H., Bhardwaj, P. K., Rani, A., Singh, R. S., Raizada, J., Singh, K., \& Kumar, S. (2011). An RNA isolation system for plant tissues rich in secondary metabolites. BMC Research 
Notes, 4(1), 85. https://doi.org/10.1186/17560500-4-85

Giovannoni, J. J. (2004). Genetic regulation of fruit development and ripening. The Plant Cell, 16(suppl. 1), S170-S180. https://doi. org/10.1105/tpc.019158

Hyakumachi, M., Nishimura, M., Arakawa, T., Asano, S., Yoshida, S., Tsushima, S., \& Takahashi, H. (2012). Bacillus thuringiensis suppresses bacterial wilt disease caused by Ralstonia solanacearum with systemic induction of defense-related gene expression in tomato. Microbes and Environments, 28(1), 128-134. https://doi.org/10.1264/jsme2.me12162

Ishihara, T., Mitsuhara, I., Takahashi, H. \& Nakaho, K. (2012). Transcriptome analysis of quantitative resistance-specific response upon Ralstonia solanacearum infection in tomato. PLOS One, 7(10), e46763. https://doi.org/10.1371/ journal.pone.0046763

Jaiswal, A. K., Alkan, N., Elad, Y., Sela, N., Philosoph, A. M., Graber, E. R., \& Frenkel, O. (2020). Molecular insights into biochar-mediated plant growth promotion and systemic resistance in tomato against Fusarium crown and root rot disease. Scientific Reports, 10(1), 13934. https:// doi.org/10.1038/s41598-020-70882-6

Li, Y., Chen, S., Liu, N., Ma, L., Wang, T., Veedu, R. N., \& Jing, X. (2020). A systematic investigation of key factors of nucleic acid precipitation toward optimized DNA/RNA isolation. BioTechniques, 68(4), 191-199. https:// doi.org/10.2144/btn-2019-0109

Liedl, B. E., Labate, J. A., Stommel, J. R., Slade, A., \& Kole, C. (2013). Genetics, genomics, and breeding of tomato. CRC Press.

Liu, L., Han, R., Yu, N., Zhang, W., Xing, L., Xie, D., \& Peng, D. (2018). A method for extracting high-quality total RNA from plant rich in polysaccharides and polyphenols using Dendrobium huoshanense. PLOS One, 13(5), e0196592. https://doi.org/10.1371/journal. pone. 0196592

Løvdal, T., \& Lillo, C. (2009). Reference gene selection for quantitative real-time PCR normalization in tomato subjected to nitrogen, cold, and light stress. Analytical Biochemistry, 387(2), 238-242. https://doi.org/10.1016/j.ab.2009.01.024

Milling, A., Babujee, L., \& Allen, C. (2011). Ralstonia solanacearum extracellular polysaccharide is a specific elicitor of defense responses in wiltresistant tomato plants. PLOS One, 6(1), e15853. https://doi.org/10.1371/journal.pone.0015853

Rajakani, R., Narnoliya, L., Sangwan, N. S., Sangwan, R. S., \& Gupta, V. (2013). Activated charcoalmediated RNA extraction method for Azadirachta indica and plants highly rich in polyphenolics, polysaccharides and other complex secondary compounds. BMC Research Notes, 6(1), 125. https://doi.org/10.1186/1756-0500-6-125

Rio, D. C. (2015). Denaturation and electrophoresis of RNA with formaldehyde. Cold Spring Harbor Protocols, 2015(2), 219-222. https://doi. org/10.1101/pdb.prot080994

Roy, D., Tomo, S., Modi, A., Purohit, P., \& Sharma, P. (2020). Optimising total RNA quality and quantity by phenol-chloroform extraction method from human visceral adipose tissue: A standardisation study. MethodsX, 7, 101113. https://doi.org/10.1016/j.mex.2020.101113

Sambrook, J., \& Russell, D. W. (2001). Molecular cloning: A laboratory manual (3rd ed.). Cold Spring Harbor Lab Press.

Toni, L. S., Garcia, A. M., Jeffrey, D. A., Jiang, X., Stauffer, B. L., Miyamoto, S. D., \& Sucharov, C. C. (2018). Optimization of phenol-chloroform RNA extraction. MethodsX, 5, 599-608. https:// doi.org/10.1016/j.mex.2018.05.011

Uner, B., Kombeci, K., \& Akgul, M. (2016). The utilization of tomato stalk in fiber production: $\mathrm{NaOH}$ and $\mathrm{CaO}$ pulping process. Wood Research, 61(6), 927-936. 
Vasanthaiah, H. K., Katam, R., \& Sheikh, M. B. Yadeta, K., \& Thomma, B. (2013). The xylem as (2008). Efficient protocol for isolation of functional RNA from different grape tissue battleground for plant hosts and vascular wilt rich in polyphenols and polysaccharides for pathogens. Frontiers in Plant Science, 4, 97. gene expression studies. Electronic Journal of Biotechnology, 11(3), 42-51. https://doi. org/10.2225/vol11-issue3-fulltext-5

Vennapusa, A. R., Somayanda, I. M., Doherty, C. J., \& Jagadish, S. K. (2020). A universal method for high-quality RNA extraction from plant tissues rich in starch, proteins and fiber. Scientific Reports, 10(1), 16887. https://doi.org/10.1038/ s41598-020-73958-5

Wang, H. M., Yin, W. C., Wang, C. K., \& To, K. Y. (2009). Isolation of functional RNA from different tissues of tomato suitable for developmental profiling by microarray analysis. Botanical Studies, 50, 115-125. 